\title{
On the constant of the sun's heat
}

\section{Maurer}

To cite this article: M. Maurer (1886) On the constant of the sun's heat, Philosophical Magazine Series 5, 22:136, 312-312, DOI: 10.1080/14786448608627936

To link to this article: http://dx.doi.org/10.1080/14786448608627936

$$
\text { 册 Published online: } 29 \text { Apr } 2009 .
$$

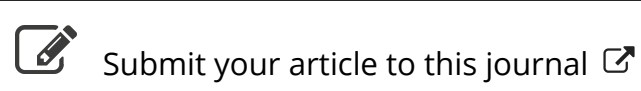

\footnotetext{
Џll Article views: 2
}

Q View related articles $\sqsubset$ 
it will be seen that the divergence obtained by this method does not exceed $\frac{1}{5}$ or.

The rest of the paper contains the establishment of the formula, and the experimental details and data.-Wiedemann's Annalen, vol. xxviii. p. 613 (1886).

\section{ON THE CONSTANT OF THE SUN'S HEAT. BY M. MAURER.}

The author compares the values for this constant, obtajned previously by Pouillet, Hagen, Crova, Violle, and Cangley; those given by Violle and Langley appear too great. This seems to arise from the fact that Langley and Violle have found too high a value for the amount of the solar radiation on the Earth's surface, while the methods of other observers, to which those of Röntgen and Exner, and Desains must be added, agree very well with each other.

Actinometric measurements have recently been made with a new apparatus of F. Weber's, under remarkably good atmospheric conditions. Six of them were made on the terrace of the Polytechnicum at Zürich, two on the top of the St. Grothard pass (2100 metres), and one on the Pizzo Centrale (3000 metres). According to these, the maximum heat from the Sun at midday, which a surface of a square centimetre receives in a minute under perpendicular radiation, is :-

$$
\begin{array}{crr}
\text { In Zurich } \ldots \ldots \ldots . . & 1.10-1.32 & \text { thermal unit. } \\
\text { On the St. Gothard ... } & 1.38-1.41 \quad, \quad \text { " } \\
\text { " Pizzo Centrale. } & 1.52 \quad "
\end{array}
$$

These agree very well with the above observations, excepting for Violle's and Langley's.-Zeitschrift der Oesterr. Gesellschaft. für Meteorologie, vol. xx. p. 296, 1885 ; Beiblätter der Physik, vol. x. p. 182 .

\section{ON THE INCREASE OF TEMPERATURE PRODUCED BY A WATEREALL. BY M. KELLER.}

The slight increase of temperature in a waterfall is powerfully affected by the sources of error which the author discusses. His observations at the waterfall at Terni should have given a difference of temperature of $0^{\circ} \cdot 37$; the measured ones varied between $0^{\circ} .08$ and $0^{\circ} .73$. The author considers these numbers an evidence of the transformation of vis viva into heat in this waterfall.-Atti della $R$ Acc. dei Lincei [4] i. pp. 671-676 (1885); Beiblätter der Physik, vol. x. p. 333. 